\title{
RADIOCARBON DATES FROM HALFIAH GIBLI (ABADIYEH), A PREDYNASTIC SETTLEMENT IN UPPER EGYPT
}

\author{
Kathryn A Bard \\ Department of Archaeology, Boston University, 675 Commonwealth Avenue, Boston, Massachusetts 02215, USA. \\ Email: kbard@bu.edu.
}

\begin{abstract}
In 1989 and 1991, wood charcoal samples were excavated at a Predynastic settlement in Upper Egypt, Halfiah Gibli (HG). A second site, Semaineh ( $\mathrm{SH}$ ), was also investigated, but as the ceramics there were mostly from the Old Kingdom, excavations were concentrated at HG. Wood charcoal was obtained in undisturbed contexts, in association with Nagada culture potsherds and lithics, ranging in date from about $3700 \mathrm{BC}$ to 3200/3100 BC. These new radiocarbon dates provide more data for the relative phases of the Nagada culture, formulated mainly from ceramic seriation.
\end{abstract}

\section{INTRODUCTION}

The Predynastic period in Egypt, when complex society arose, spans most of the 4th millennium BC, culminating in about 3100-3000 BC with the emergence of Egypt's Early Dynastic state. While a number of Predynastic cemeteries have been excavated, beginning with Flinders Petrie's excavation of over 2000 burials at Nagada in 1894-95 (Petrie and Quibell 1896), Predynastic settlements have not been well preserved and their excavation was frequently overlooked in favor of the much more spectacular burial evidence.

In 1989, initial investigations (surface survey and several $1 \times 1 \mathrm{~m}$ test excavations) were conducted by K Bard at the Predynastic settlements of Halfiah Gibli (HG) and Semaineh (SH) in Upper Egypt $\left(26^{\circ} 00^{\prime} \mathrm{N}, 32^{\circ} 22^{\prime} \mathrm{E}\right)$. These 2 Predynastic sites were later excavated in 1991.

Sites HG and SH were first mentioned by Petrie in his well-known volume, Diospolis Parva, The Cemeteries of Abadiyeh and Hu (1901), in which his Sequence Dating system for seriating Predynastic pottery was explained. This ceramic seriation system was later modified by Werner Kaiser (1957), and as a result, the 3 relative phases of Predynastic culture are now called Nagada I, II, and III, after the largest-known Predynastic site. More recently, several studies of ${ }^{14} \mathrm{C}$ dates from settlements have been published by Hassan (Hassan 1984; Hassan 1985; Hassan and Robinson 1987), and an absolute chronology of the Nagada culture relative phases has been collated by Hendrickx (1996: 64) based on Hassan's radiocarbon dates. ${ }^{14} \mathrm{C}$ dates obtained from wood and matting excavated at Abydos (cemeteries U, B, and the Early Dynastic royal cemetery) by the German Institute of Archaeology, Cairo, provide an even longer sequence of calibrated dates, from the Nagada Ib phase to the end of the 1st Dynasty but with a long gap in dates between the Nagada Ic and Nagada IId phases (Görsdorf et al. 1998).

Table 1 Hendrickx's Absolute Chronology of the Predynastic Nagada Culture

\begin{tabular}{ll}
\hline Period & cal BC \\
\hline Nagada Ia-IIb & approximately 3900-3650 BC \\
Nagada IIc-IId2 & approximately 3650-3300 BC \\
Nagada IIIa1-IIIb/Dyn. 0 & approximately 3300-3100 BC
\end{tabular}

The purpose of this article is to provide further correlation between the relative dates of Nagada culture phases and ${ }^{14} \mathrm{C}$ dates. 


\section{METHODS}

Situated on spurs of the low desert above the floodplain and to the south of the el-Ranan canal, both HG and SH sites were deflated and had been disturbed by modern cultivation and/or farming activities (Bard 1989). In 1989 and 1991, charcoal samples were collected from deposits in the remaining areas that did not seem to have been disturbed by later human activity. During the excavations, relative dates were given to the excavated deposits using Kaiser's (1957) seriation of Predynastic Nagada culture pottery classes.

The 1991 excavations at $\mathrm{SH}$ revealed a site with a great mixture of ceramics, predominantly dating to the Old Kingdom (about 2686-2125 BC) but mixed with a few Predynastic and New Kingdom sherds. As SH seemed to be an Old Kingdom site, excavations were discontinued there. Petrie had excavated a cemetery area $(\mathrm{H})$ at Semaineh on a small spur east of the settlement and this area is probably where the mainly Nagada III grave goods were found (Bard 1992).

The 1991 excavations at HG revealed the settlement associated with the Predynastic cemetery (Abadiyeh) excavated by Petrie. There was no evidence of any structures at the site and 9 units were excavated in the few undisturbed deposits, i.e., in margins to the north and east of the main spur (Bard 1992). All of the ceramics excavated at HG are from the Nagada Ic to Nagada IIb-c phases (Sally Swain, personal communication).

Excavated charcoal samples were collected with metal trowels, and were then wrapped in aluminum foil and placed in plastic sample bags.

The 1989 charcoal samples were submitted to the Oxford Radiocarbon Accelerator, Research Laboratory for Archaeology. The 1991 charcoal samples were submitted to the Radiocarbon Laboratory of the Institute for the Study of Earth and Man at Southern Methodist University (Dallas, Texas, USA), under the direction of Herbert Haas. This laboratory later moved and became the WRC Radiocarbon Laboratory, Water Resources Center, Desert Research Institute (Las Vegas, Nevada, USA).

Table 2 Calibrated ${ }^{14} \mathrm{C}$ dates from the predynastic sites of Halfiah Gibli and Semaineh

\begin{tabular}{|c|c|c|c|c|}
\hline \multirow[b]{2}{*}{ Sample No. } & \multirow[b]{2}{*}{ Lab No. } & \multirow[b]{2}{*}{ BP } & \multicolumn{2}{|c|}{ Calibration } \\
\hline & & & $68.2 \%$ & $95.4 \%$ \\
\hline HG-1 & OxA-2182 & $4590 \pm 80 \mathrm{BP}$ & $\begin{array}{l}3510 \mathrm{BC}(19.8 \%) 3420 \mathrm{BC} \\
3390 \mathrm{BC}(19.5 \%) 3300 \mathrm{BC} \\
3240 \mathrm{BC}(28.9 \%) 3100 \mathrm{BC}\end{array}$ & $3650 \mathrm{BC}(95.4 \%) 3000 \mathrm{BC}$ \\
\hline HG-2 & OxA-2183 & $4810 \pm 80 \mathrm{BP}$ & $\begin{array}{l}3700 \mathrm{BC}(2.8 \%) 3680 \mathrm{BC} \\
3670 \mathrm{BC}(61.5 \%) 3510 \mathrm{BC} \\
3400 \mathrm{BC}(3.9 \%) 3380 \mathrm{BC}\end{array}$ & $\begin{array}{l}3760 \mathrm{BC}(78.7 \%) 3490 \mathrm{BC} \\
3470 \mathrm{BC}(16.7 \%) 3370 \mathrm{BC}\end{array}$ \\
\hline SH-3 & OxA-2184 & $4860 \pm 80 \mathrm{BP}$ & $\begin{array}{l}3760 \mathrm{BC}(46.5 \%) 3620 \mathrm{BC} \\
3600 \mathrm{BC}(21.7 \%) 3520 \mathrm{BC}\end{array}$ & $3950 \mathrm{BC}(95.4 \%) 3350 \mathrm{BC}$ \\
\hline SH-4 & OxA-2185 & $4020 \pm 80 \mathrm{BP}$ & $\begin{array}{l}2850 \mathrm{BC}(4.7 \%) 2810 \mathrm{BC} \\
2670 \mathrm{BC}(61.8 \%) 2450 \mathrm{BC} \\
2420 \mathrm{BC}(1.7 \%) 2400 \mathrm{BC}\end{array}$ & 2900 BC (95.4\%) $2300 \mathrm{BC}$ \\
\hline HG-50 & DRI-2833 & $4604 \pm 91 \mathrm{BP}$ & $\begin{array}{l}3520 \mathrm{BC}(46.2 \%) 3310 \mathrm{BC} \\
3240 \mathrm{BC}(12.0 \%) 3170 \mathrm{BC} \\
3160 \mathrm{BC}(10.0 \%) 3100 \mathrm{BC}\end{array}$ & $3650 \mathrm{BC}(95.4 \%) 3000 \mathrm{BC}$ \\
\hline SH-150 & DRI-2907 & $4933 \pm 136 \mathrm{BP}$ & $\begin{array}{l}3950 \mathrm{BC}(17.7 \%) 3840 \mathrm{BC} \\
3820 \mathrm{BC}(47.7 \%) 3630 \mathrm{BC} \\
3560 \mathrm{BC}(2.8 \%) 3530 \mathrm{BC}\end{array}$ & $4050 \mathrm{BC}(95.4 \%) 3350 \mathrm{BC}$ \\
\hline
\end{tabular}


Table 2 Calibrated ${ }^{14} \mathrm{C}$ dates from the predynastic sites of Halfiah Gibli and Semaineh Continued

\begin{tabular}{|c|c|c|c|c|}
\hline \multirow[b]{2}{*}{ Sample No. } & \multirow[b]{2}{*}{ Lab No. } & \multirow[b]{2}{*}{ BP } & \multicolumn{2}{|c|}{ Calibration } \\
\hline & & & $68.2 \%$ & $95.4 \%$ \\
\hline \multirow[t]{2}{*}{ HG-332 } & DRI-2834 & $5060 \pm 110 \mathrm{BP}$ & $3970 \mathrm{BC}(63.5 \%) 3750 \mathrm{BC}$ & $4250 \mathrm{BC} \quad(1.7 \%) 4100 \mathrm{BC}$ \\
\hline & & & $3740 \mathrm{BC} \quad(4.7 \%) 3710 \mathrm{BC}$ & $4050 \mathrm{BC}(93.7 \%) 3600 \mathrm{BC}$ \\
\hline \multirow[t]{2}{*}{ HG-341 } & ETH-13011 & $4680 \pm 65 \mathrm{BP}$ & $3620 \mathrm{BC} \quad(5.3 \%) 3600 \mathrm{BC}$ & $3640 \mathrm{BC}(95.4 \%) 3340 \mathrm{BC}$ \\
\hline & & & $3530 \mathrm{BC}(62.9 \%) 3360 \mathrm{BC}$ & \\
\hline \multirow[t]{3}{*}{ HG-349 } & DRI-2835 & $4290 \pm 140 \mathrm{BP}$ & $3100 \mathrm{BC}(43.5 \%) 2830 \mathrm{BC}$ & $3350 \mathrm{BC}(95.4 \%) 2450 \mathrm{BC}$ \\
\hline & & & $2820 \mathrm{BC}(22.5 \%) 2660 \mathrm{BC}$ & \\
\hline & & & $2650 \mathrm{BC} \quad(2.2 \%) 2620 \mathrm{BC}$ & \\
\hline \multirow[t]{3}{*}{ HG-526 } & DRI-2906 & $4498 \pm 131 \mathrm{BP}$ & $3370 \mathrm{BC}(66.6 \%) 3010 \mathrm{BC}$ & $3550 \mathrm{BC}(95.4 \%) 2850 \mathrm{BC}$ \\
\hline & & & $2980 \mathrm{BC} \quad(0.8 \%) 2970 \mathrm{BC}$ & \\
\hline & & & $2950 \mathrm{BC} \quad(0.8 \%) 2930 \mathrm{BC}$ & \\
\hline \multirow[t]{2}{*}{ HG-545 } & SMU-2754 & $4860 \pm 70 \mathrm{BP}$ & $3720 \mathrm{BC}(46.8 \%) 3620 \mathrm{BC}$ & $3800 \mathrm{BC}(92.5 \%) 3500 \mathrm{BC}$ \\
\hline & & & $3590 \mathrm{BC}(21.4 \%) 3520 \mathrm{BC}$ & $3430 \mathrm{BC} \quad(2.9 \%) 3380 \mathrm{BC}$ \\
\hline HG-655 & DRI-2905 & $4731 \pm 132 \mathrm{BP}$ & $3650 \mathrm{BC}(68.2 \%) 3360 \mathrm{BC}$ & $3800 \mathrm{BC}(95.4 \%) 3050 \mathrm{BC}$ \\
\hline
\end{tabular}

RESULTS, 1989 SAMPLES

Four samples of wood charcoal were taken in test pits at HG and SH. The calibrated dates of these samples were previously published (Bard 1991), but have been re-calibrated here using OxCal v3.8 (Bronk Ramsey 2002).

HG-1, OxA-2182

${ }^{14} \mathrm{C}$ age: $4590 \pm 80 \mathrm{BP}$
Cal age(s), $68.2 \%$ probability: $3510 \mathrm{BC}(19.8 \%) 3420 \mathrm{BC}$
$339 \mathrm{BC}(19.5 \%) 3300 \mathrm{BC}$
$3240 \mathrm{BC}(28.9 \%) 3100 \mathrm{BC}$
$95.4 \%$ probability: $3650 \mathrm{BC}(95.4 \%) 3000 \mathrm{BC}$

Wood charcoal taken $5-10 \mathrm{~cm}$ below the surface in an ancient midden in the uncultivated area of HG, at the bottom of a small wadi full of Predynastic sherds and lithics, which had washed down the slope. Collected 1989 by K Bard.

Comment: Calibrated dates of this sample fall within Hendrickx's phase of Nagada IIc-IId2, about 3650-3300 BC, the middle Nagada phase.

HG-2, OxA-2183

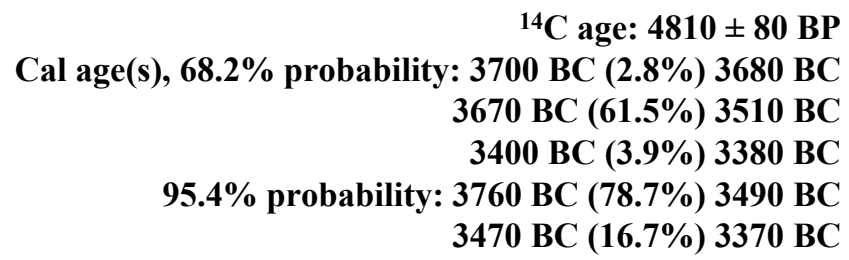

Wood charcoal taken $5-10 \mathrm{~cm}$ below the surface in a small, ancient midden in the uncultivated area of HG. Collected 1989 by K Bard.

Comment: Calibrated dates of this sample fall within Hendrickx's phase of Nagada IIc-IId2, about 3650-3300 BC, the middle Nagada phase, but earlier than sample HG-1, OxA-2182.

SH-3, OxA-2184

${ }^{14} \mathrm{C}$ age: $4860 \pm 80 \mathrm{BP}$

Cal age(s), 68.2\% probability: 3760 BC (46.5\%) 3620 BC

3600 BC (21.7\%) 3520 BC

95.4\% probability: 3950 BC (95.4\%) 3350 BC

Wood charcoal taken $5-10 \mathrm{~cm}$ below the surface of a test pit in an area south of a mudbrick feature visible on the surface of the site. Collected 1989 by K Bard. 
Comment: This date is from the earliest phase of Predynastic culture (Hendrickx's Nagada Ia-IIb, about 3900-3600 BC).

SH-4, OxA-2185

${ }^{14} \mathrm{C}$ age: $4020 \pm 80 \mathrm{BP}$

Cal age(s), $68.2 \%$ probability: $2850 \mathrm{BC}(4.7 \%) 2810 \mathrm{BC}$

2670 BC (61.8\%) 2450 BC

2420 BC (1.7\%) 2400 BC

95.4\% probability: 2900 BC $(95.4 \%) 2300$ BC

Wood charcoal taken $5-10 \mathrm{~cm}$ below the surface in a test pit within a rectangular feature of decayed mudbrick. Collected 1989 by K Bard.

Comment: This feature can now be dated to the Old Kingdom. The presence of predominantly Old Kingdom sherds on the surface of this site helps to explain this date.

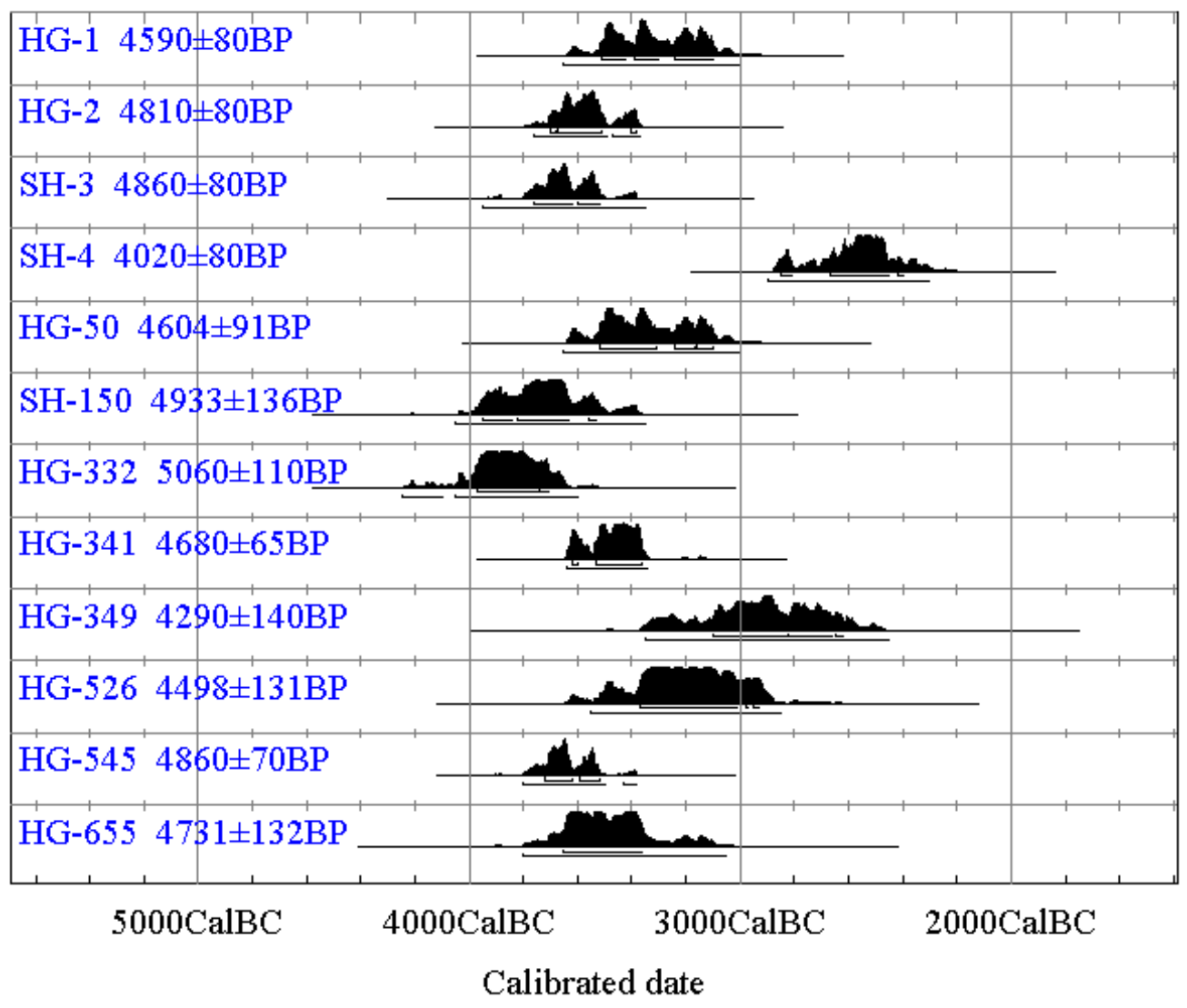

Figure $1{ }^{14} \mathrm{C}$ dates for Halfiah Gibli (HG) and Semaineh (SH). Atmospheric data from Stuiver et al (1993), Oxcal v3.8 Bronk Ramsey (2002), cub r:4 sd:12 prob usp[chron]

\section{RESULTS, 1991 SAMPLES}

Eight samples of wood charcoal were taken from excavated units at HG and SH. A 9th sample (HG399, DRI 2836) "came out very small, and its conversion to benzene was a speculative undertaking"

(Haas, personal communication). Hence, this sample is not listed here. Calibration uses OxCal v3.8 (Bronk Ramsey 2002). 
Wood charcoal excavated in a deposit of gravelly silt about $15-30 \mathrm{~cm}$ below the surface that had been washed down from the main settlement along with a number of Predynastic artifacts, mainly potsherds and lithics. Collected 1991 by H Raab-Rust.

Comment: This redeposited sample and associated artifacts suggest movement of village artifacts and ecofacts by wadi activity after Nagada culture occupation of the site.

SH-150, DRI-2907

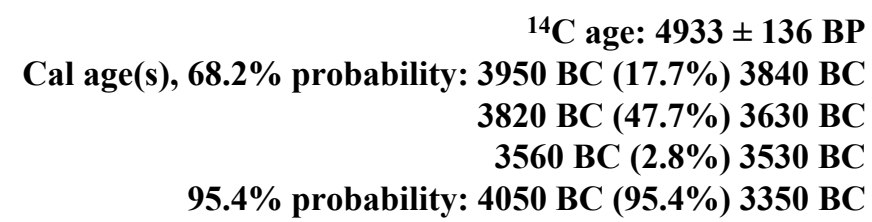

Wood charcoal sample found next to a Meydum ware sherd (Old Kingdom) 5-10 cm below the surface. Other pottery in this feature, which was thought to be a kiln for Old Kingdom bread molds, was a great mixture of Old and New Kingdom wares with some Predynastic potsherds. The majority of sherds were Old Kingdom bread molds. Collected 1991 by S Savage.

Comment: Although this sample was collected in an Old Kingdom context, its calibrated dates are much earlier, suggesting a disturbed feature with a mixture of artifacts from different periods (Predynastic and Old Kingdom).

HG-332, DRI-2834

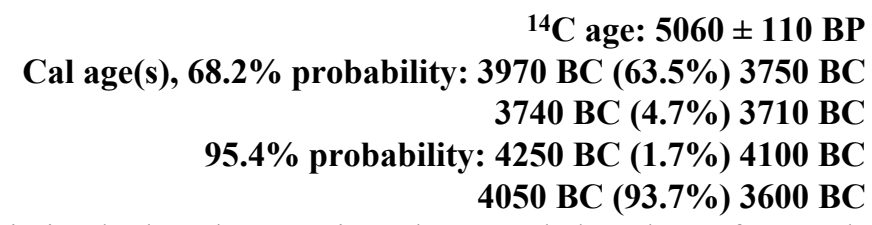

Wood charcoal associated with a semi-circular hearth approximately $77 \mathrm{~cm}$ below the surface. Collected 1991 by H Raab-Rust.

Comment: No pottery or lithics were found associated with this hearth, excavated well below the stratigraphic location of all Predynastic artifacts. It is the earliest date obtained at this site, possibly predating Nagada culture occupation there.

HG-341, ETH-13011

$$
\begin{array}{r}
{ }^{14} \mathrm{C} \text { age: } 4680 \pm 65 \mathrm{BP} \\
\text { Cal age(s), } 68.2 \% \text { probability: } 3620 \mathrm{BC}(5.3 \%) 3600 \mathrm{BC} \\
3530 \mathrm{BC}(62.9 \%) 3360 \mathrm{BC} \\
95.4 \% \text { probability: } 3640 \mathrm{BC}(95.4 \%) 3340 \mathrm{BC}
\end{array}
$$

Wood charcoal taken in a test pit approximately $40 \mathrm{~cm}$ below the surface (and below the plow zone) in the Predynastic settlement that had been disturbed by cultivation in the 1950s and 1960s. Collected 1991 by K Bard.

Comment: This sample was taken just above the dark red paleosol, and although the artifacts in the test pit demonstrate post-Predynastic disturbance, the calibrated dates of the sample suggest a Nagada IIc-IId2 date for the occupation of the HG village (see Hendrickx 1996:64). 
HG-349, DRI-2835

${ }^{14} \mathrm{C}$ age: $4290 \pm 140 \mathrm{BP}$

Cal age(s), 68.2\% probability: $3100 \mathrm{BC}(43.5 \%) 2830 \mathrm{BC}$ 2820 BC (22.5\%) 2660 BC 2650 BC (2.2\%) $2620 \mathrm{BC}$

95.4\% probability: 3350 BC $(95.4 \%) 2450$ BC

Wood charcoal taken in a deposit approximately $5-20 \mathrm{~cm}$ below the surface in which the only sherds of marl ware were found at HG. Marl ware is more commonly found in Predynastic burials and is much less common in settlement contexts. Collected 1991 by J Raab-Rust.

Comment: The deposit contained much ash and few artifacts, which the project paleoethnobotanist, Wilma Wetterstrom, thought might represent ashy deposits that were removed from village houses and dumped on the edge of the village (Wetterstrom, personal communication). The calibrated dates of the sample, however, are later than the Predynastic.

HG-526, DRI-2906

${ }^{14} \mathrm{C}$ age: $4498 \pm 131 \mathrm{BP}$

Cal age(s), 68.2\% probability: $3370 \mathrm{BC}(66.6 \%) 3010 \mathrm{BC}$

2980 BC $(0.8 \%) 2970$ BC

2950 BC (0.8\%) 2930 BC

95.4\% probability: $3550 \mathrm{BC}(95.4 \%) 2850 \mathrm{BC}$

Wood charcoal excavated about $5-10 \mathrm{~cm}$ below the surface in a deposit in the undisturbed area of the main Predynastic settlement, just above the dark red paleosol. Collected 1991 by J Raab-Rust.

Comment: The calibrated dates would suggest the latest occupation of the Predynastic village, in the Nagada IIIa1-IIIc1 phases (see Hendrickx 1996:64).

HG-545, SMU-2754

${ }^{14} \mathrm{C}$ age: $4860 \pm 70 \mathrm{BP}$

Cal age(s), $68.2 \%$ probability: $3720 \mathrm{BC}(46.8 \%) 3620 \mathrm{BC}$

$3590 \mathrm{BC}(21.4 \%) 3520 \mathrm{BC}$

95.4\% probability: $3800 \mathrm{BC}(92.5 \%) 3500 \mathrm{BC}$

3430 BC (2.9\%) 3380 BC

Wood charcoal excavated about $10-15 \mathrm{~cm}$ below the surface in the area of a lithics workshop, in which there was abundant charcoal and lenses of ash. Collected 1991 by K Bard.

Comment: Also in this feature was the end fragment of a ground greywacke rhomboid-shaped palette, as found in Predynastic graves dating to late Nagada I and early Nagada II phases (about 3650 BC, Hendrickx 1996:64). The relative dates of these burials would accord well with the calibrated dates of the sample.

HG-655, DRI-2905

${ }^{14} \mathrm{C}$ age: $4731 \pm 132 \mathrm{BP}$

Cal age(s), 68.2\% probability: $3650 \mathrm{BC}(68.2 \%) 3360 \mathrm{BC}$

95.4\% probability: 3800 BC $(95.4 \%) 3050$ BC

Wood charcoal excavated approximately $10-15 \mathrm{~cm}$ below the surface in deposits of overlapping ash and sand lenses with abundant charcoal, lithics, and a Nagada Ic C-class sherd. Collected 1991 by S Savage.

Comment: The calibrated age of $3650 \mathrm{BC}$ would be appropriate for the Nagada Ic sherd.

\section{CONCLUSION}

Wood charcoal taken from the excavated units at site HG is Predynastic in date, whereas wood charcoal from site SH is Predynastic and Old Kingdom in date. The contexts of these samples indicate 
disturbance of the sites in ancient and modern times and at HG, there is also evidence of slope wash and erosion.

There is no evidence at HG of any kind of permanent settlement, however, and occupation may have been sporadic and/or seasonal. Given a lack of such evidence, possibly another more permanent settlement existed on the floodplain and is now destroyed or covered with river sediments. The existence of such a site would explain the presence of a large Predynastic cemetery (B) that Petrie excavated at Abadiyeh with a number of high-status burials.

A calibrated date of 3800-3500 BC (HG-545, SMU-2754) for wood charcoal from a lithics workshop, in which a fragment of a rhomboid-shaped palette was found, accords well with a relative date of Nagada Ic-IIa for this artifact. This calibrated date, along with that of another sample (HG-655, DRI-2905) associated with a Nagada Ic C-class potsherd, would place the transition from Nagada I to Nagada II at about $3600 \mathrm{BC}$.

Wood charcoal (HG-332, DRI-2834) excavated at HG under a deep deposit of sterile, windblown sand, and associated with a hearth but no potsherds or lithics, provides evidence of the earliest use of the site, possibly predating the occupation of Nagada culture peoples.

Both sites HG and SH were in use in the Old Kingdom, as the calibrated dates of several samples demonstrate, at which time there was much disturbance of the earlier Predynastic debris.

Calibrated dates of samples from $\mathrm{HG}$ of the 4th millennium BC indicate a Predynastic village occupied from about 3700 BC (HG-545, SMU-2754) to about 3200/3100 BC (HG-526, DRI-2906). Although the site was disturbed in ancient and recent times, wood charcoal samples collected in contexts with Predynastic potsherds and lithics provide more relative and absolute dates for the Predynastic Nagada culture.

\section{ACKNOWLEDGMENTS}

Funding for this project was provided by grants from the National Geographic Society, Committee for Research and Exploration. The author gratefully acknowledges their support of this project.

I would also like to thank Andrea Manzo of the Instituto Universitario Orientale, Naples, Italy, for calibrating the dates $\mathrm{BC}$ of the 12 charcoal samples from sites $\mathrm{HG}$ and $\mathrm{SH}$, which he very generously offered to do in 2000. In 2003, Larry Pavlish of the Department of Physics (Isotope), University of Toronto, calibrated the dates of the 12 samples using an updated program. Sally Swain was the project's ceramic analyst who studied the excavated potsherds and placed them in a relative sequence based on Werner Kaiser's seriation (1957).

\section{REFERENCES}

Bard KA. 1989. Predynastic settlement patterns in the Hu-Semaineh Region, Egypt. Journal of Field Archaeology 16:475-78.

Bard KA. 1991. Egypt, Halfiah Gibli and Semaineh H, Hiw. In: Hedges REM, Houseley RA, Bronk RA, van Klinken GJ. Radiocarbon dates from the Oxford AMS System: Archaeometry Datelist 12. Archaeometry 33(1):129-30.

Bard KA. 1992. Preliminary report: the 1991 Boston University excavations at Halfiah Gibli and Semaineh, Upper Egypt. Newsletter of the American Re-

search Center in Egypt 158/159:11-5.

Hassan FA. 1984. Radiocarbon chronology of Predynastic Naqada settlements, Egypt. Current Anthropology 25:681-3.

Hassan FA. 1985. Radiocarbon chronology of Neolithic and Predynastic sites in Upper Egypt and the Delta. African Archaeological Review 3:95-116.

Hassan FA, Robinson SW. 1987. High-precision radiocarbon chronometry of ancient Egypt and comparisions with Nubia, Palestine and Mesopotamia. Antiquity 61:119-35. 
Hendrickx S. 1996. Relative chronology of the Naqada Culture. Problems and possibilities. In: Spencer J. Aspects of Early Egypt. London: British Museum Press. p 36-69.

Görsdorf J, Dreyer G, Hartung U. 1998. New ${ }^{14} \mathrm{C}$ dating of the Archaic Royal Necropolis Umm el-Qaab at Abydos (Egypt). Radiocarbon 40(2):641-7.
Kaiser W. 1957. Zur inneren Chronologie der Naqadakultur. Archaeologia Geographica 5/6:69-77. Petrie WMF, Quibell JE. 1896. Naqada and Ballas. London: British School of Archaeology in Egypt.

Petrie WMF. 1901. Diospolis Parva. The Cemeteries of Abadiyeh and $H u$. London: Egypt Exploration Fund. 